\title{
ROLE OF DYSPLASTIC FEATURES IN EVALUATION OF QT INTERVAL DISORDER IN PATIENTS WITH SMALL HEART ANOMALIES
}

\author{
Yagoda A. V. ${ }^{1}$, Grigoryan Ya. S. ${ }^{2}$, Gladkikh N. N. $^{1}$
}

1 Stavropol State Medical University, Russian Federation
2 Regional Clinical Cardiology Center, Stavropol, Russian Federation

S mall heart anomalies are a heterogeneous group of cardiovascular system development disorder in the form of anatomical abnormalities of heart structure and great vessels which occurred in embryoor ontogenesis [8, 10]. Small heart anomalies are usually being interpreted as pathology only in cases of overt forms (arrhythmias, clinically significant valvular regurgitation, etc) and rarely being considered from these positions in relation to young people - even on a stage of occupational guidance or military medical examination. Meanwhile, small heart anomalies are one of the pathologies which caused high-frequency of rhythm disorder (from $50 \%$ up to $90 \%$ ) including young age and development of sudden arrhythmic death [11]. This is precisely why timely detection is important in population of small heart anomalies of patients with high risk of cardiovascular complications, first of all, arrhythmia.

One of the risk factor of dangerous arrhythmia and sudden cardiac death is long/short QT interval $[5,12]$. In case of hereditary QT prolongation one can observe specific gene mutations, disorder of genetic control of ion channel proteins with electrophysiological consequences. Data comparison of genetic research with associated phenotypic manifestations of different molecular genetic variations of long and short QT syndrome made it possible to refine their diagnostics on the stage proceeding to genotyping. In recent years there is an active search for new mutations takes place and diagnostics of so called «silent» pathology forms which are being manifested under certain conditions is still actual [9]. In addition to this, there is lack of information in literature about frequency and clinical significance of changes

Yagoda Alexander, MD, PhD, Professor, Head of Departmen of Hospital Therapy, Stavropol State Medical University; tel.: 89064907330, e-mail: alexander.yagoda@gmail.com

Grigoryan Yana, Functional diagnostics specialist of State Budgetary Institution of Health Care of Stavropol region «Regional Clinical Cardiologic Center».

tel.: 89280095104; e-mail: 89280095104@mail.ru

Gladkikh Nataliya, MD, reader of hospital

therapy of State Budgetary Educational Institution of High

Professional Education. Stavropol State Medical University;

tel.: (8652)295309; e-mail: ngladkih@mail.ru in QT interval in young patients with small heart anomalies.

At present stage the small heart anomalies are recommended to be considered from a position of certain dysplastic syndromes and phenotypes [6]. Diagnosis of changes in QT interval on the basis of clinicophenotypic analysis methodology in patients with small heart anomalies is still actual. This approach will allow to improve efficiency of prevention measures for this pathology.

Aim of research: to define peculiarities of dysplastic syndromes and phenotypes in patients with small heart anomalies and changes in QT interval and to evaluate their diagnostic significance in relation to QT duration/shortening.

Material and Methods. 128 patients (78 men and 50 women, aged $22.8 \pm 0.3$ years) with small heart anomalies were examined. Inclusion criteria: written informed consent for participation in research, presence of small heart anomalies, identified T-wave ending on electrocardiogram (ECG). Exclusion criteria: hereditary syndromes, diseases and states tightly associated with QT interval duration disorder, drug treatment.

Echocardiographic ventricular false tendons were detected in 94 patients, mitral valve prolapse 81 patients, open oval window - 23 patients, aneurysm of interatrial septum - 18 patients, bicuspid aortic valve - 9 patients, aneurysm of ventricular septum - 5 patients, tricuspid valve prolapse - 4 patients. Additional groups of papillary muscles, diagonal trabecule, aneurism of Valsalva sinus, aortic valve prolapse, subvalvular memberane of aorta and enlarged eustachian valve were detected in rare cases. Small heart anomalies occurred as isolated cases (38.3\%) and as combination in $2-5$ cases $(61.7 \%)$.

Control group was composed of 20 health people of appropriate gender and age without small heart anomalies and signs of connective tissue dysplasia.

Dysplastic features were diagnosed [6]. ECG was recorded («Shiller AT-1»). Three cycles in Il-lead were measured from primary point of QRS complex (junction of baseline of segment $P-Q(R)$ in $Q(R)$ )-wave till late point of T-wave in its junction into baseline $\mathrm{T}-\mathrm{P}$ and its average value was estimated [12, 13]. Absolute QT interval value was compared to standard value at different heart rate and depending on patient's gender. H. C. Bazet's formulas at $R-R<1.0$ sec and 
L. S. Fridericia formulas at $R-R>1.0 \mathrm{sec}$ were used for heart rate correction of QT interval (QTcor) [cit. 5]. Automated QTcor duration measurements were performed according to data of Holter ECG monitoring («Kardiotekhnika-04», JSC «Inkart», St.Petrsburg), maximum interval duration for any period of time was calculated. QTcor duration was interpreted in accordance with recommendations of European Agency for the Evaluation of Medical Products [13].

Program «AtteStat» was used for statistical data analysis. When analyzing qualitative features criteria $\chi^{2}$ was used. Diagnostic value of features was determined by their sensitivity, specificity, predictive validity at positive and negative results and precision, Odds Ration (OR) was calculated. Differences at $\mathrm{p}<0.05$ were considered as proven.

Results and Discussion. Lipothymia with QT interval prolongation (38.3 \%) and asymptomatic long QT interval (30.6\%) turned to be more frequent clinic forms of pathologic QT. Syncope with long QT interval (16.3\%), lipothymia with short QT interval (8.2\%) and asymptomatic short QT interval (61\%) occurred more rarely.

Deviations of QT interval were detected in 49 patients with small heart anomalies (38.3\%; $\left.\chi^{2}=9,8, p=0.002\right)$. Dominant interval duration disorder was its prolongation (85.7\% cases of QT changes).

Prevalence of short and long QT interval in patients with small heartanomalies can be explained by several reasons. First reason is pathology of cardiac ion channels: hereditary channelopathy manifesting by long or short QT syndromes, it is also considered as intracardiac anomalies. Second reason is occurrence of structural cardiac changes in forms of small heart anomalies which contributes to cardiac remodeling and occurrence of early or late postdepolarizations; the third reason is genetically pre-determined or acquired magnesium deficiency [7].

Great attention is also paid to magnesium deficiency in pathogenesis of connective tissue dysplasia. Capability of fibroblasts to produce collagen is being disordered under magnesium deficiency [3]. It can be assumed that systemic connective tissue dysplasia lays the basis for QT interval disorders in patients with small heart anomalies. Therefore, disorder of electric systole of ventricular in this patients' category also can be allelically determined.

The following dysplastic phenotypes were diagnosed in patients with small heart anomalies: mitral valve prolapse syndrome (21.1\% of cases), marfanoid habitus $(7.8 \%)$, phenotype similar to Ehler-Danlos (0.8\%), benign joint hypermobility (12,5 \%) and non-classified phenotype (30.5\%).

Detection of well-known dysplastic syndrome and phenotype in $27.3 \%$ patients with small heart anomalies has failed. This group was composed of people with enhanced dysplastic stigmatization.

Prevalence of changes in QT interval was registered more frequently in patients with mitral valve prolapse syndrome, marfanoid habitus, and benign joint hypermobility (ref. Table).
Prevalence of pathological QT interval at various dysplastic syndromes and phenotypes in patients with small heart anomalies

\begin{tabular}{|l|c|c|c|}
\hline \multicolumn{1}{|c|}{$\begin{array}{c}\text { Dysplastic syndrome } \\
\text { or phenotype }\end{array}$} & $\begin{array}{c}\% \\
\text { patients }\end{array}$ & $x^{2}$ & $p$ \\
\hline $\begin{array}{l}\text { Mitral valve prolapse } \\
(n=27)\end{array}$ & 44.4 & 9.7 & 0.002 \\
\hline $\begin{array}{l}\text { Marfanoid habitus } \\
(n=10)\end{array}$ & 80.0 & 17.9 & $<0.0001$ \\
\hline $\begin{array}{l}\text { Unclassified phenotype } \\
(n=39)\end{array}$ & 20.5 & 3.2 & 0.076 \\
\hline $\begin{array}{l}\text { Benign joints hypermobility } \\
(n=16)\end{array}$ & 75.0 & 19.4 & $<0.0001$ \\
\hline $\begin{array}{l}\text { Enhanced dysplastic } \\
\text { stigmatization ( } n=35)\end{array}$ & 22.9 & 3.66 & 0.055 \\
\hline
\end{tabular}

Estimation of diagnostic significance of dysplastic syndromes and phenotypes in detection of QT duration disorder was obtained. Mitral valve prolapse syndrome had high specificity $(81 \%)$ for verification of changes in QT interval. Marfanoid habitus and benign joint hypermobility had high specificities (98.7\% and $94.9 \%$ correspondingly) and positive predictive values $(87.5 \%$ and $75 \%)$. Marfanoid habitus (OR 13.0; $95 \%$ Cl 1.6-109.2; $\mathrm{p}<0.05$ ) and benign joint hypermobility (OR 6.1; $95 \% \mathrm{Cl} 1.8-20.1 ; \mathrm{p}<0.05)$ were characterized as significant risk factors of QT interval disorder.

Issue about interaction between osseous features of connective tissue dysplasia and cardiovascular disregulation deserves special discussion in the opinion of E. V. Zemtsovsky [2]. Gene mutation of receptors of transforming growth factor (TGF)- $\beta$ which are accompanied by cytokines elevated concentration on the different stages of embryogenesis can cause either structural cardiac connective tissue changes or structural changes of osseous system [2]. Classic complex of Holt-Oram anomalies includes a lot of skeletal development defects (hypoplasia of radial bone, scoliosis, pectus excavatum) and cardiac defects - septal defects, mitral valve prolapse, etc. [4].

Estimation of cytokine profile in formation of cardiac and osseous features of connective tissue dysplasia has shown significant increase of TGF- $\beta 1$ level and basic fibroblast growth factor (FGF-b) in patients with mitral valve prolapsed, pectus excavatum, scoliosis and joint hypermobility. High serum concentration of interleukin- $1 \beta$, TGF- $\beta 1$, FGF-b distinguished patients with myxomatous mitral valve prolapse [1].

Prevalence of long/short QT interval had increased significantly in cases of myxomatous mitral valve prolapse $(66.7 \%)$ compared to nonmyxomatous mitral valve prolapse $(16.7 \%$, $\mathrm{p}=0.027$ ). Further analysis revealed that myxomatous mitral valve prolapse has predictive 
value in relation to long/short QT interval (OR 3.8; $95 \% \mathrm{Cl} 1.2-11.8 ; \mathrm{p}<0.05)$, whereas such value in case of non-myxomatous mitral valve prolapse was not found (OR 0.3; $95 \% \mathrm{Cl} \mathrm{0.1-1.4;} \mathrm{p>0.05).}$

Therefore, detection of myxomatous mitral valve prolapse, marfanoid habitus and benign joints hypermobility in patients with small heart anomalies can serve as marker of undiagnosed QT duration change. The latter is especially important if considering non-syncopal course of long/short QT interval in $83.7 \%$ patients with small heart anomalies.

Prevalence of asymptomatic forms of QT elongation/shortening turned out to be one of the reasons of high frequency disorder of common electric systole duration in young patients with small heart anomalies $(32.0 \% ; p<0.05)$ newly verified during our research.

It is apparent that during examination the patients with small heart anomalies there must be suspicion in relation to detection changes in QT interval.

\section{References}

1. Gladkikh N. N. Mitral valve prolapse: clinical and pathogenic analysis from the position of connective tissue dysplasia: Author's thesis, Doctor of Medical Science ... Stavropol; 2009.

2. Zemtsovsky E. V., Reeva S. V., Timofeev S. V. et al. About frequency of cardiac rhythm disorder and its variability rate in people with marfanoid habitus. Vestnik of arrhythmology. 2010;59:47-52.

3. Klemenov A. V. Undifferent connective tissue dysplasia. Moscow; 2005.

4. Kozlova S. I., Demikova N. S, Semanova E. et al. Hereditary syndromes and genetic counseling. M.; 1996.

5. Limankina I. N. Long QT interval syndrome and safety problems of psycho- pharmacotherapy. Vestnik of arrhythmology. 2008;52:66-71.

6. Hereditary connective tissue disorder in cardiology. Diagnostic and treatment. Russian recommendations (I revision). Moscow; 2012.

7. Rezvan V. V., Yakob O. V., Kataeva Yu. S. Clinical and electrocardiographic syndromes associated with risk of sudden death. Clinical medicine. 2008;5:55-61.

\section{ROLE OF DYSPLASTIC FEATURES IN EVALUATION OF QT INTERVAL DISORDER IN PATIENTS WITH SMALL HEART ANOMALIES \\ YAGODA A. V., GRIGORYAN Y. S., GLADKIKH N. N.}

To assess relation of dysplastic syndromes and phenotypes to pathological QT interval in patients with small heart anomalies, 128 patients aged between 18-35 years were examined. High frequency of QT interval duration disorder (38.3 \%) without any clinical manifestations was found. QT interval duration disorders were associated with myxomatous mitral valve prolapse, marfanoid habitus and benign joints hypermobility.

Key words: small heart anomalies, connective tissue dysplasia, QT interval
It is necessary to consider character of dysplastic syndrome or phenotype when developing algorithm of early diagnosis of asymptomatic course of QT interval elongation/shortening in young patients with small heart anomalies.

\section{Conclusion}

1. High frequency of QT interval duration disorder (38.3\%) primarily in non-syncopal forms was detected in patients with small heart anomalies.

2. There is relationship between pathologic QT frequency and dysplastic phenotype character: interval duration disorder in patients with small heart anomalies associated with myxomatous mitral valve prolapse, with marfanoid habitus and benign joints hypermobility.

3. Patients with myxomatous mitral valve prolapse, marfanoid habitus and benign joints hypermobility need to be stratify in risk group of QT interval elongation/shortening, monitor heart rhythm, affect on modifiable reasons of its changes including medication.

8. Trisvetova E. L. Small heart anomalies. Minsk; 2006.

9. Shkolnikova M. A., Kharlap M. S., Ildarova R. A. et al. Diagnosis, sudden death risk stratification and treatment of the main molecular genetic forms of long QT interval syndrome. Kardiology. 2011;5:50-61.

10. Yagoda A. V., Gladkikh N. N. Small heart anomalies. Stavropol; 2005.

11. Yakovlev V. M., Karpov R. S., Belan Yu. B. Arrhythmia and cardiac conduction disorder at connective-tissue cardiac dysplasia. Omsk; 2001.

12. (The ESC textbook of Cardiovascular Medicine) Cardiac and vessel diseases. Guidelines of European Society of Cardiology. Edited by A. John Camm, Thomas F. Luscher, Patrick W. Serruys; translated from English, edited. M.; 2011.

13. Rautaharju P. M., Surawicz B., Gettes L. S. AHA/ACCF/ HRS Recommendations for the Standardization and Interpretation of the Electrocardiogram Part IV: The ST Segment, T and $U$ Waves, and the QT Interval. J. Am. Coll. Cardiol. 2009;53:982-991.

\section{РОАЬ АИСПААСТИЧЕСКИХ ПРИЗНАКОВ В ОЦЕНКЕ ИЗМЕНЕНИЙ QТ-ИНТЕРВААА У ПАЦИЕНТОВ С МААЫМИ АНОМААИЯМИ СЕРАЦА \\ А. В. Я્રГОАА, Я. С. ГРИГОРЯН, \\ H. Н. ГАА $\triangle К И Х$}

С целью определения клинической значимости диспластических синдромов и фенотипов в верификации патологического интервала QT у пациентов с малыми аномалиями сердца обследовано 128 пациентов в возрасте от 18 до 35 лет. Выявлена высокая распространенность нарушений продолжительности интервала QT в большинстве случаев с отсутствием клинических проявлений. Нарушения длительности интервала QT были ассоциированы с миксоматозной дегенерацией ПМК, марфаноподобным фенотипом и доброкачественной гипермобильностью суставов.

Ключевые слова: малые аномалии сердца, дисплазия соединительной ткани, QT-интервал 